\title{
Response of growth and development of the Pacific oyster (Crassostrea gigas) to thermal discharge from a nuclear power plant
}

\author{
Zhi-guo Dong ${ }^{1,2^{*}}$, Yi-hua Chen ${ }^{1,2}$, Hong-xing Ge ${ }^{1,2}$, Xiao-ying Li ${ }^{1,2}$, Hai-long Wu ${ }^{1,2}$, Chen-he Wang ${ }^{1}$, Zhe Hu',
} Yang-jian $\mathrm{Wu}^{1}$, Guang-hui Fu' ${ }^{3}$, Ji-kun $\mathrm{Lu}^{3}$ and Hua Che ${ }^{4}$

\begin{abstract}
Background: During electricity generation of nuclear power plant, heat energy cannot be completely converted into electrical energy, and a part of it is lost in the form of thermal discharge into the environment. The thermal discharge is harmful to flora and fauna leading to environmental deterioration, biological diversity decline, and even biological extinction.

Results: The present study investigated the influence of thermal discharge from a nuclear power plant on the growth and development of Pacific oyster Crassostrea gigas which is widely used as bio indicator to monitor environmental changes. The growth of soft part and the gonad development of oysters were inhibited due to thermal discharge. During winter season, temperature elevation caused by thermal discharge promoted the growth of oyster shells. During summer season, the growth rate of oysters in thermal discharge area was significantly lower than that of the natural sea area.

Conclusions: The results of this study provided a better understanding of assessing the impact of thermal discharge on the marine ecological environment and mariculture industry. It also provided a scientific basis for defining a safe zone for aquaculture in the vicinity of nuclear power plants.
\end{abstract}

Keywords: Nuclear power plant, Thermal discharge, Crassostrea gigas, Growth and development

\section{Background}

China is one of the fastest growing countries in nuclear power industry in the world. So far, the number of nuclear power plants in China has reached to 34 and 20 nuclear power plants are being built, accounting for $40 \%$ of the total number of nuclear power plants in the world. China has a total installed nuclear power capacity of 53 , 613 MW (e) as of July, 2017 [1]. However, an inherent problem in electricity generation is that the energy generated in the reactor cannot be converted into electrical

\footnotetext{
*Correspondence: dzg7712@163.com

1 Jiangsu Key Laboratory of Marine Bioresources and environment, Jiangsu Key Laboratory of Marine Biotechnology, Huaihai Institute of Technology, Lianyungang 222005, Jiangsu, China

Full list of author information is available at the end of the article
}

energy [2]. Any reactor for that matter even a thermal power plant needs huge quantity of water for cooling the condenser and process water [3]. Considering the huge need of cooling water, nuclear power plants are mostly located in coastal areas. Nuclear power plants use seawater from the coastal area as a coolant for cooling the condenser by heat exchange. The warm water after extracting heat was released back into the sea directly $[4,5]$. Thermal discharge as a source of pollution entering the sea increases the water temperature locally or regionally leading to thermal pollution [6].

Thermal pollution will not only increase the temperature of the seawater, but also change the physical and chemical properties. The rise in temperature will also lead to reduction in dissolved oxygen $[7,8]$ and increase 
the concentration of nitrogen and phosphorus in seawater [9]. The intensity and speed of temperature elevation at the sea surface can have a significant effect on biological growth, metabolism, reproduction and life cycle [10]. Researchers have found that temperature elevation can increase in the abundance of temperature-tolerant taxa [11], but it also reduces the abundance of temperaturesensitive species $[12,13]$. Therefore, change in temperature is an important factor that results in decline of marine population and habitat destruction [14].

Changes in temperature will directly affect bivalves, because most of them are sessile, sedentary and immobile [15]. Moreover, in comparison to fish and other marine organisms, bivalves have a very low level enzyme system activity capable of metabolizing persistent pollutants [2]. Hence, bivalves are usually considered sensitive indicators of marine pollution [16-18]. Oysters are sessile and temperature sensitive bivalves. A considerable amount of research has been carried out to monitor the environment using oysters as an indicator [19-22].

China is one of the largest oyster farming countries in the world; in 2015, the total production of oysters exceeded 4573 million $\mathrm{t}$, accounting for $33.7 \%$ of the total production of the total yield of shellfish [23]. Therefore, the high yield and quality of oysters is very important for the economic development of marine culture. However, the build-up of nuclear power plants, especially thermal discharge, has brought new challenges to the traditional farming model. Hence it is very important to research the growth and development of oysters under the influence of thermal discharge from nuclear power plants.

Tianwan Nuclear Power Plant (TWNPP), located on the coast of the Yellow Sea, has been running for 10 years since May 17, 2007 [24]. The reactor of TWNPP was VVER-1000/428 which was designed based on the Russian standard reactor type VVER-1000/320 [25]. Unit I was operated in 2007, and it had two pressurized water reactor, each of $1060 \mathrm{MW}(\mathrm{e})$ capacity. Unit II will operate in December 2018, the capacity of pressurized water reactor will be $1100 \mathrm{MW}(\mathrm{e})$. TWNPP operated with a cooling system and required $96.88 \mathrm{~m}^{3} \mathrm{~s}^{-1}$ of cooling water [26]. After extracting heat, the thermal discharge was subsequently released back into the sea. In this study, we carried out the experiments in three sampling stations in the vicinity of TWNPP up to a distance of $14.20 \mathrm{~km}$ on either side of the plant. The growth and development characteristics of oyster shells, meat yield (MY) and gonadosomatic index (GSI) were determined in order to assess the effect of thermal discharge from nuclear power plant on the growth and development of oysters. This will provide a better understanding of response of growth and development of the Pacific oyster to thermal discharge from a nuclear power plant.

\section{Methods}

Study area

Haizhou Bay, which is adjacent to the TWNPP $\left(34^{\circ} 41^{\prime}\right.$ $13^{\prime \prime} \mathrm{N}, 119^{\circ} 27^{\prime} 53^{\prime \prime} \mathrm{E}$ ), was selected as the study area. Three research stations, S1 $\left(34^{\circ} 42^{\prime} 56^{\prime \prime} \mathrm{N}, 119^{\circ} 30^{\prime} 24^{\prime \prime}\right.$

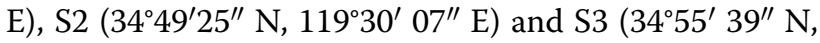
$\left.119^{\circ} 30^{\prime} 45^{\prime \prime} \mathrm{E}\right)$, which are the principal oyster farming areas in Haizhou Bay were selected to carry out the present experiments (Fig. 1). S3 was taken as control area for it is far from the nuclear power plant (straight-line distance from the outfall $14.20 \mathrm{~km}$ ) and the seawater temperature was not affected by thermal discharge. Chosen as the test area, S1 was closest to the outfall $(4.92 \mathrm{~km})$ and another station $\mathrm{S} 2,8.46 \mathrm{~km}$ away from the outfall also was selected in transition area.

The straight-line distance from the intake to the TWNPP is $5.21 \mathrm{~km}$, and the outfall near the TWNPP. The temperature at the intake and outfall were showed in Table 1 from December 1, 2015 to April 30, 2016.

\section{Oyster collection and data acquisition}

Oysters were cultured by long line culture. We used scallop shells for holdfast, the seedling rope suspension was cultured in floating rope, and the length of rope for inserting seeding was $1.2 \mathrm{~m}$. Oyster seeds were cultured at the sample stations on November 11, 2015. The initial gross weight was $12.50 \pm 0.57 \mathrm{~g}$, and the shell height $(\mathrm{SH})$, shell length (SL) and shell width (SW) were $3.45 \pm 0.38$, $2.32 \pm 0.37$, and $1.15 \pm 0.28 \mathrm{~cm}$, respectively.

50 samples of oyster were collected randomly at each sample station during the trial and were kept in foam boxes with ice packs. In the laboratory, the SH, SL and SW of oysters were measured using vernier caliper (accuracy of $0.02 \mathrm{~mm}$,) according to published methods [27, 28 ] as shown in Fig. 2. In addition, we measured the gross weight, wet meat and gonad weight using electronic balance (accuracy of $0.0001 \mathrm{~g}$ ) in order to calculate the MY and GSI. The formulas used to calculate the MY and GSI were as follows:

$$
\text { MY }(\%)=\frac{\text { wet meat weight }}{\text { gross weight }} \times 100 \%
$$

[29],

$$
\text { GSI }(\%)=\frac{\text { gonad weight }}{\text { wet meat weight }} \times 100 \%
$$

[30].

\section{Measurement of environmental parameters}

At the sample stations, the water temperature at $0.5 \mathrm{~m}$ below the surface was measured using a calibrated 


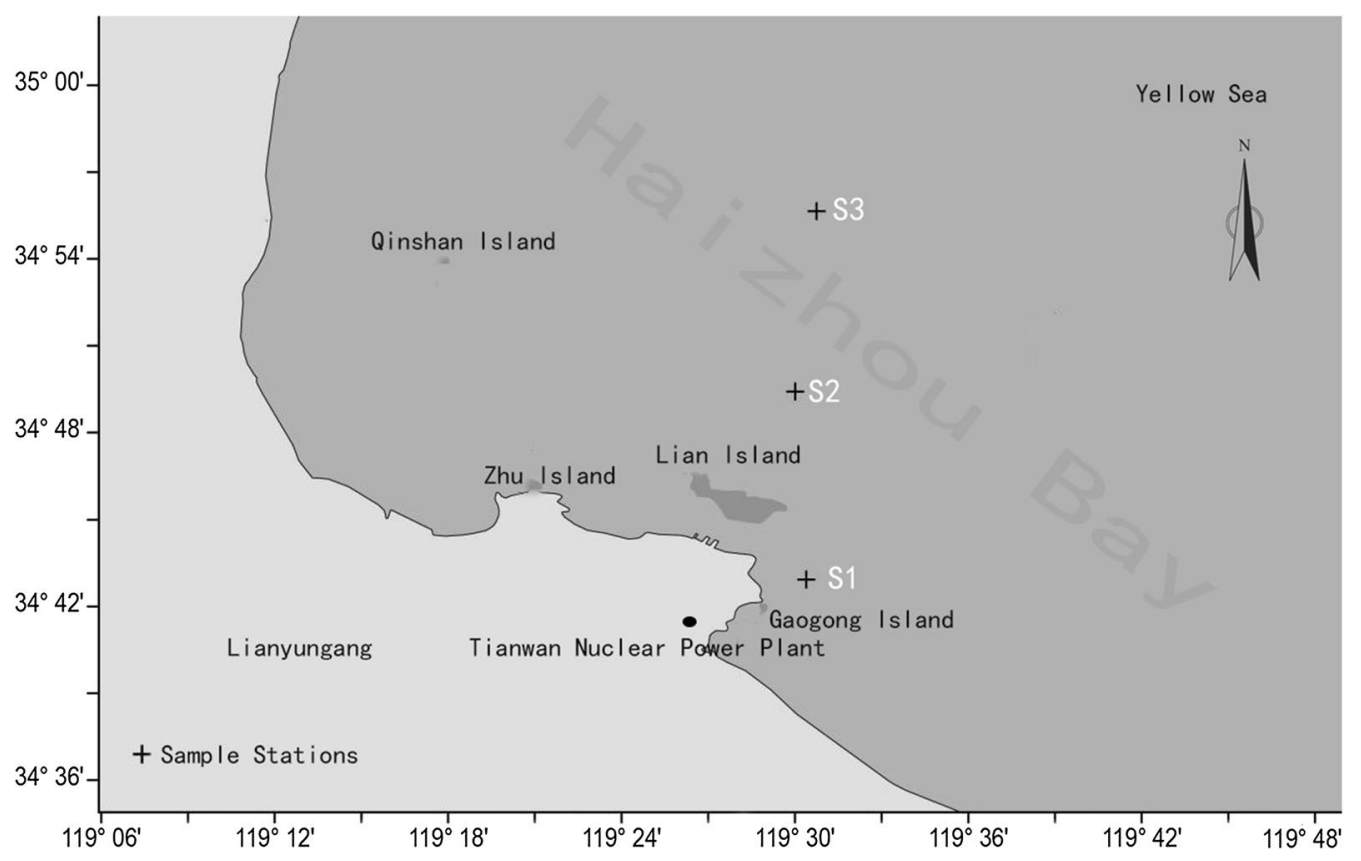

Fig. 1 Study area and sample stations in Haizhou Bay

Table 1 The temperature at the intake and outfall of the TWNPP

\begin{tabular}{llccccccc} 
& Dec-1, 2015 & Dec-22, 2015 & Jan-12, 2016 & Feb-2, 2016 & Feb-24, 2016 & Mar-18, 2016 & Apr-7, 2016 & Apr-30, 2016 \\
\hline Intake temperature $\left({ }^{\circ} \mathrm{C}\right)$ & 11.2 & 8.9 & 7.2 & 5.3 & 6.2 & 7.6 & 13.4 & 21.8 \\
Outfall temperature $\left({ }^{\circ} \mathrm{C}\right)$ & 73.4 & 72.2 & 70.6 & 66.2 & 69.8 & 71.2 & 73.6 & 75.2 \\
\hline
\end{tabular}

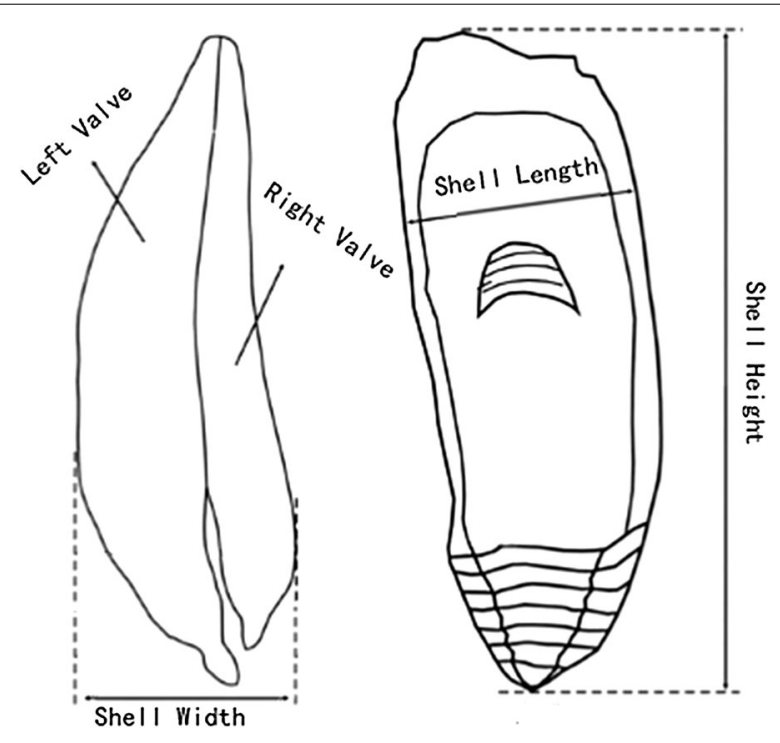

Fig. 2 Diagram showing method of measuring the height, length, and width of oyster valves mercury thermometer (accuracy of $0.2{ }^{\circ} \mathrm{C}$ ). And water samples for nutrients were collected from 10 to $15 \mathrm{~cm}$ below the sea surface with a $2 \mathrm{~L}$ water sampler. Water samples were stored in sampling bottle with a volume of $500 \mathrm{~mL}$ and kept on ice (about $4{ }^{\circ} \mathrm{C}$ ) until measurements were made in lab. Concentrations of total nitrogen (TN) and total phosphorus (TP) were measured according to colorimetric methods (GB 17378.4-2007).

Water samples for phytoplankton were collected by vertical trawl from the bottom to the sea surface with a plankton net $\left(0.37 \mathrm{~m}\right.$ diameter, $0.1 \mathrm{~m}^{2}$ mesh area, $77 \mu \mathrm{m}$ mesh size) [31]. After collection, samples were preserved in $5 \%$ formaldehyde immediately. Phytoplankton were observed and counted on a scaled slide $(0.1 \mathrm{~mL})$ using a light microscope [32, 33].

\section{Statistical analysis}

All statistical analyses were conducted using SPSS software (v.17.0 SPSS Inc.). Comparisons between groups 
were tested by one-way analysis of variance (One-Way ANOVA) and Duncan test. The result was expressed as mean $\pm \mathrm{SD}$, differences were considered to be significant at $P<0.05$.

\section{Results}

Variation of temperature at sample stations

Temperature at S1, S2 and S3 were in the following ranges: $5.8-22.4,4.4-19.6$, and $3.8-18.3{ }^{\circ} \mathrm{C}$, respectively. The mean temperatures at $\mathrm{S} 1, \mathrm{~S} 2$ and $\mathrm{S} 3$ were $10.5 \pm 5.5$,
$8.8 \pm 5.1$ and $8.1 \pm 4.8{ }^{\circ} \mathrm{C}$, respectively. The temperature at $\mathrm{S} 1$ was significantly higher $(P<0.05)$ than that of $\mathrm{S} 2$ and S3 during the whole experiment (Fig. 3), however, there were no significant differences $(P>0.05)$ between S2 and S3.

\section{Growth of $C$. gigas shells}

Variation of $\mathrm{SH}$

The growth of $\mathrm{SH}$ was consistent over the three sample stations (Fig. 4). The mean values of SH at S1, S2 and S3

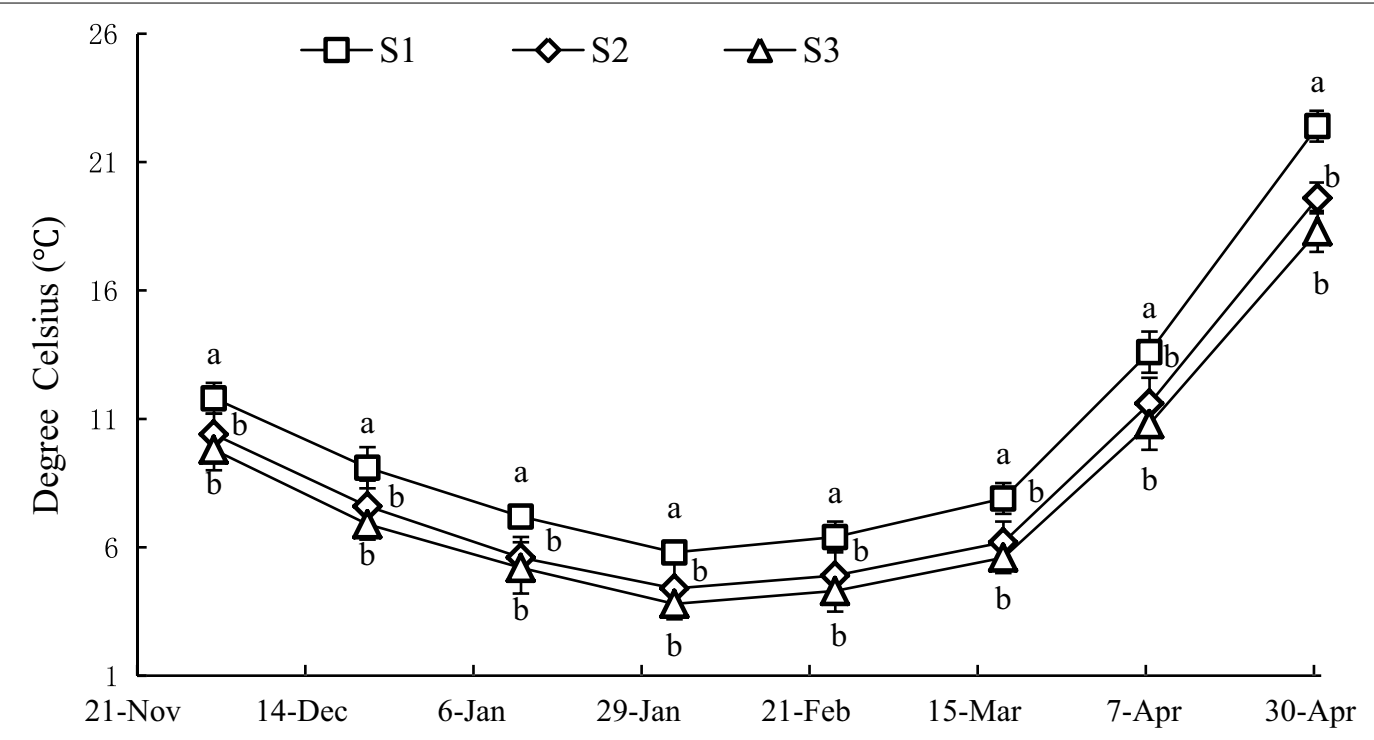

Fig. 3 Variation of temperature at sample stations. Different letters of the same sampling date indicate significant difference at 0.05

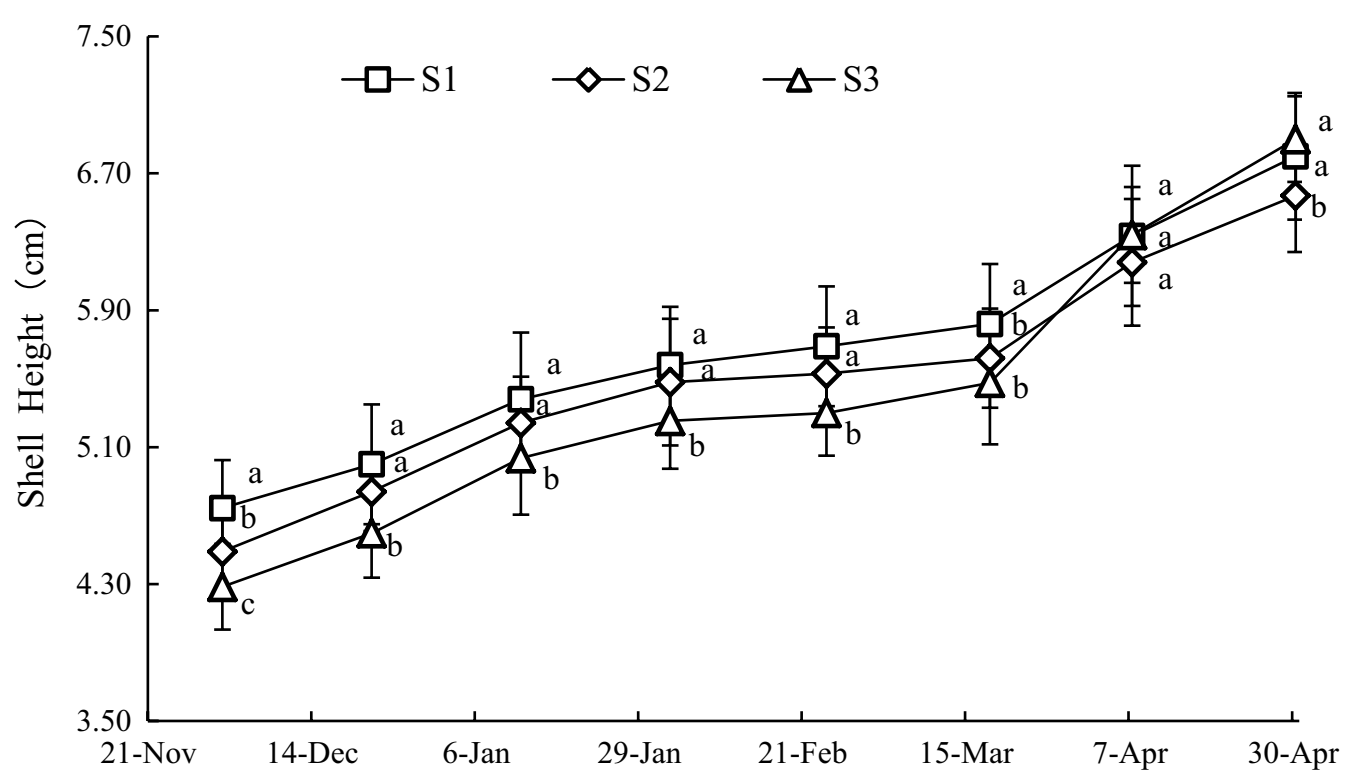

Fig. 4 Variation of SH at sample stations. Different letters of the same sampling date indicate significant difference at 0.05 
were $5.67 \pm 0.72,5.48 \pm 0.72$ and $5.41 \pm 0.93 \mathrm{~cm}$, respectively. The $\mathrm{SH}$ at $\mathrm{S} 1$ was significantly larger $(P<0.05)$ than that of S3 before March 18, 2016. Significant increment of $\mathrm{SH}$ was observed among the three sample stations after March 18, 2016. And the growth of SH at S3 was the greatest. On April 7, 2016, the SH at S3 had exceeded the others, and there were no significant differences $(P>0.05)$ among the three sample stations.

\section{Variation of $S L$}

The growth of SL at all sample station showed similar patterns as SH (Fig. 5). The mean values of SL at S1, S2 and $\mathrm{S} 3$ were $3.93 \pm 0.53,3.74 \pm 0.56$ and $3.57 \pm 0.65 \mathrm{~cm}$, respectively. Before March 18, 2016, the SL showed continuous growth, and the SL at S1 was significantly larger $(P<0.05)$ than that of S3. After March 18, 2016, significant increment of SL was observed at the three sample stations. The SL at S3 was still the smallest on April 7, 2016, however, it exceeded the SL at S2 on April 30, 2016 $(P>0.05)$, and it was still lower than that at $S 1(P>0.05)$.

\section{Variation of SW}

The growth of SW was showed in Fig. 6, the mean values of SW at S1, S2 and S3 were 1.85 $\pm 0.20,1.72 \pm 0.21$ and $1.67 \pm 0.32 \mathrm{~cm}$, respectively. The maximum of SW was observed in S1, followed by S2 and S3 on February 24,2016 , and there were significant differences $(P<0.05)$ among the three sample stations. However, the SW at S3 exceeded S2 on April 7, $2016(P<0.05)$, and it was still significantly lower than $\mathrm{S} 1(P>0.05)$. On April 30, 2016, the SW of S3 was higher than that of S1, however, there were no significant differences between the two $(P>0.05)$.

\section{Variation of MY at the three sample stations}

The MY of oysters at S3 was the highest over the duration of the experiment, followed by S2 and S1 (Fig. 7). The mean values of MY at S1, S2 and S3 were $18.42 \pm 2.71 \%$, $20.53 \pm 3.72 \%$, and $23.12 \pm 5.45 \%$, respectively. The MY at $\mathrm{S} 3$ was significantly greater $(P<0.05)$ than that of $\mathrm{S} 1$ and S2 before November 22, 2015, however, there were no significant differences $(P>0.05)$ between S1 and S2 at the same time. After November 22, 2015, there were significant differences $(P<0.05)$ among the three sample stations.

\section{Variation of GSI at the three sample stations}

The GSI of oysters at S3 was the highest for the duration of the experiment, followed by S2 and S1 (Fig. 8). The mean values of GSI at S1, S2 and S3 were $18.84 \pm 6.72 \%$, $21.32 \pm 6.39 \%$ and $24.93 \pm 8.88 \%$, respectively. Throughout the experiment, the GSI at S3 was significantly greater $(P<0.05)$ than that of S1 and S2, however, there were no significant differences $(P>0.05)$ between the S1 and $\mathrm{S} 2$.

\section{Variation in phytoplankton density at the three sample stations}

During the trial, the phytoplankton density decreased at first and then increased (Fig. 9). The phytoplankton density at S1 was the highest from December 1, 2015 to February 24, 2016, followed by S2 and S3. After February 24,

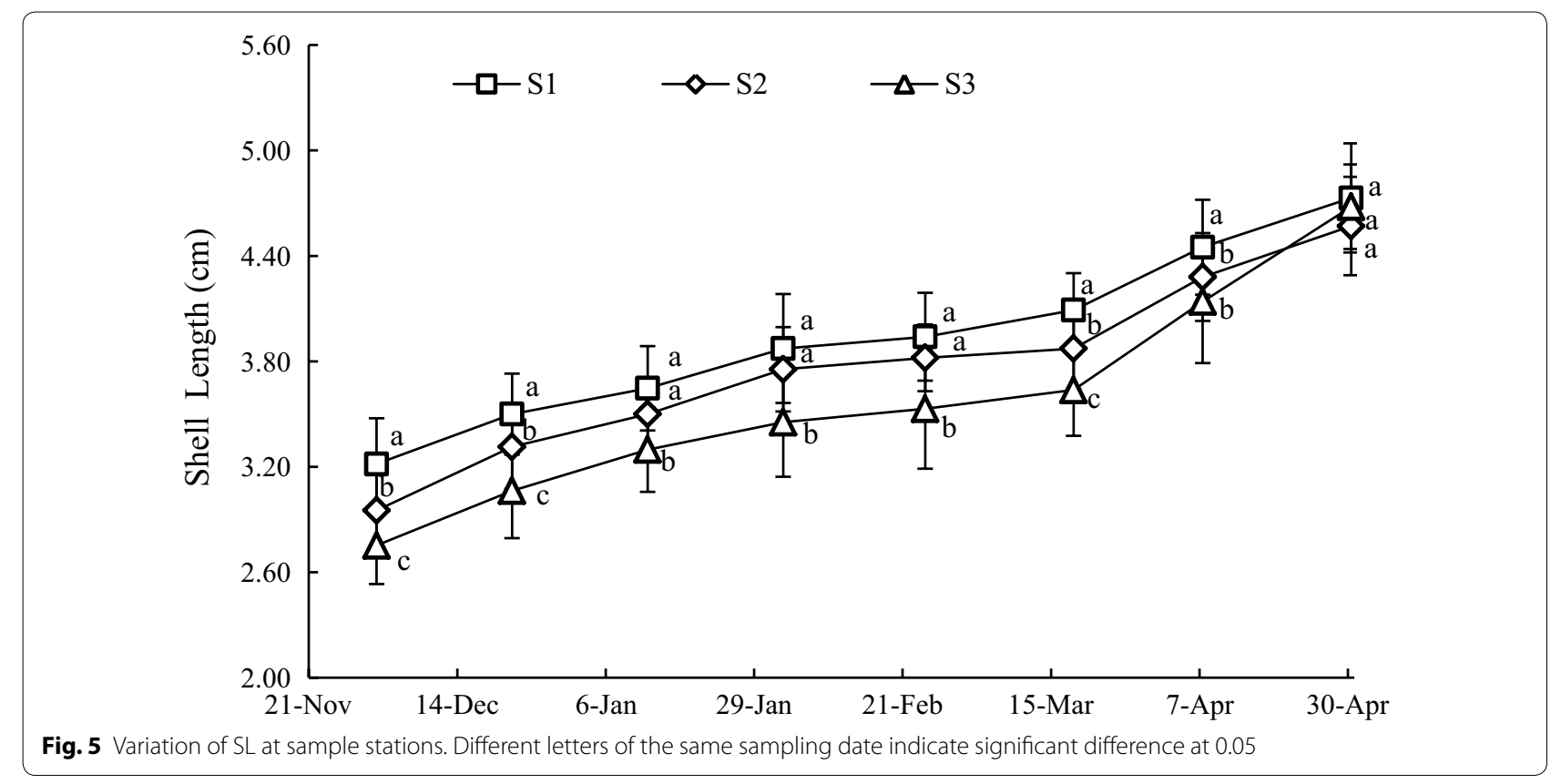




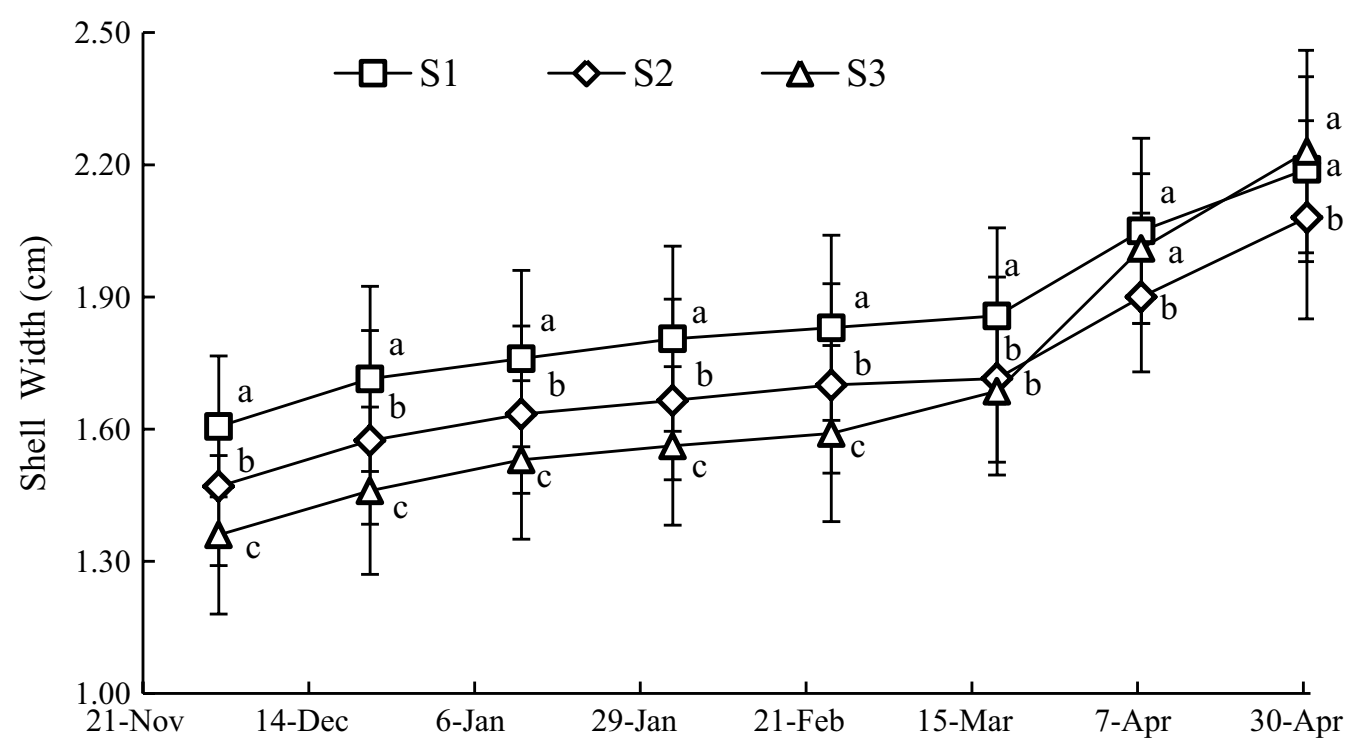

Fig. 6 Variation of SW at sample stations. Different letters of the same sampling date indicate significant difference at 0.05

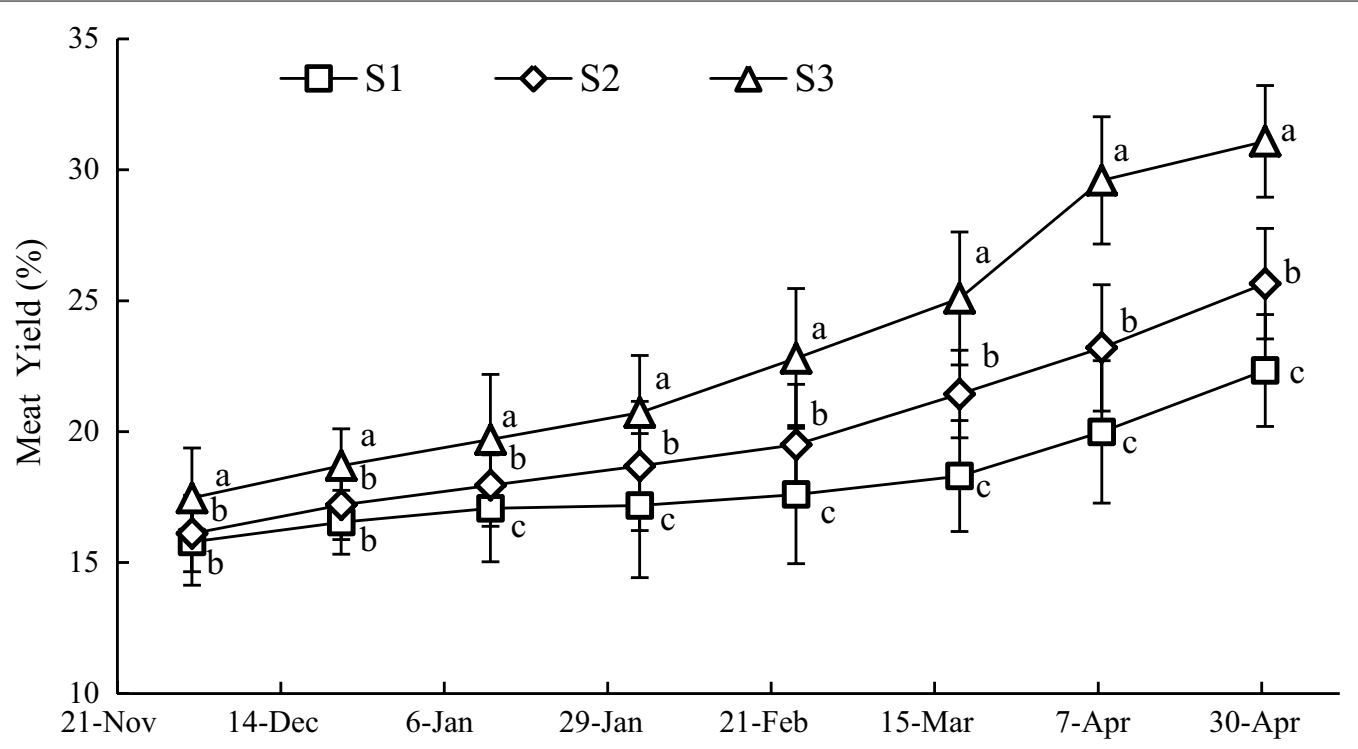

Fig. 7 Variation of MY at sample stations. Different letters of the same sampling date indicate significant difference at 0.05

2016, the phytoplankton density rose sharply, and there were significant differences $(P<0.05)$ among the three sample stations. After March 18, 2016, the phytoplankton density at S3 was the highest, followed by S1 and S2.

\section{Discussion}

It is difficult to convert thermal energy into electric energy completely during the operation of a nuclear power plant; part of the thermal energy enters the receiving water in the form of thermal discharge, which directly results in a raised seawater temperature. Research has shown that the temperature is over $4{ }^{\circ} \mathrm{C}$ higher than the receiving water and it may cause thermal pollution if the thermal discharge into the ocean occurs for a long time [34]. Normally, thermal discharge from power generating plants is roughly $10^{\circ} \mathrm{C}$ warmer than receiving waters [35]. $\mathrm{S} 1$ is closest to the nuclear power plant outfall, and the seawater is most affected. In our study, S1 had the highest water temperature over the duration of the experiment, and the mean value of the temperature was $2{ }^{\circ} \mathrm{C}$ higher 


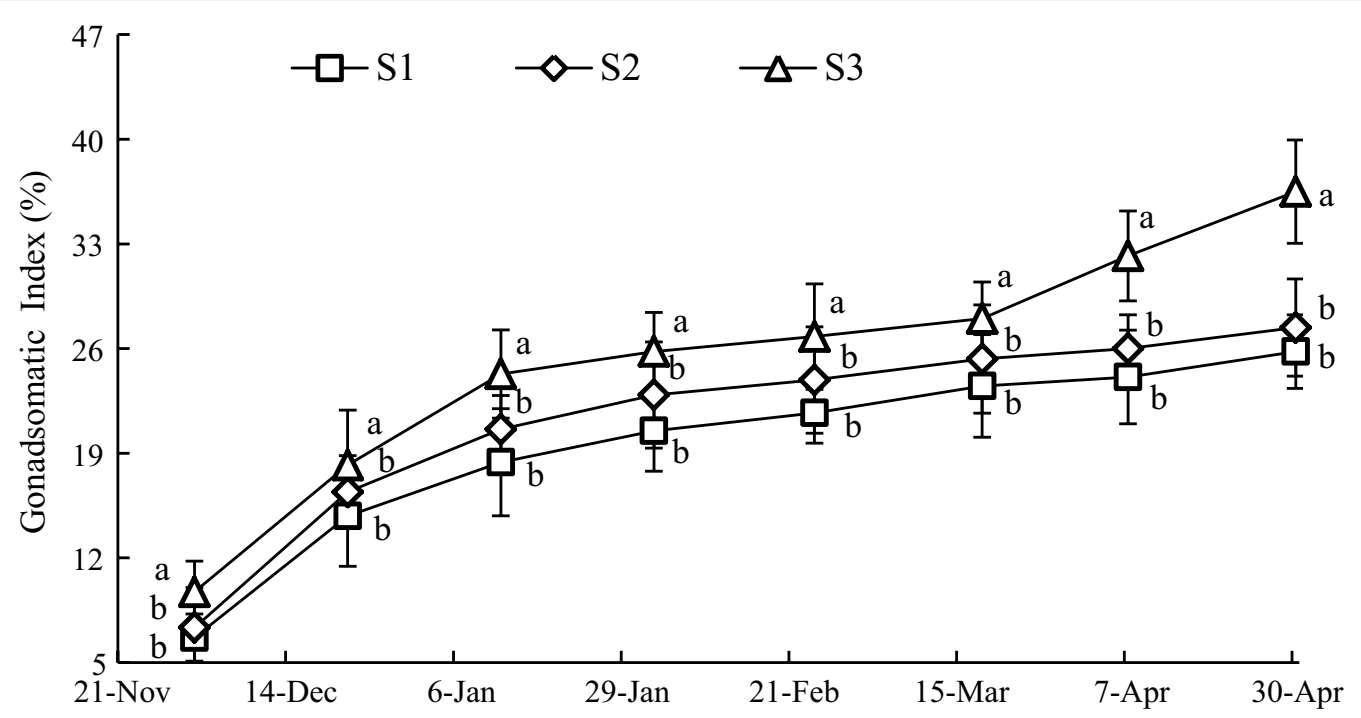

Fig. 8 Variation of GSI at sample stations. Different letters of the same sampling date indicate significant difference at 0.05

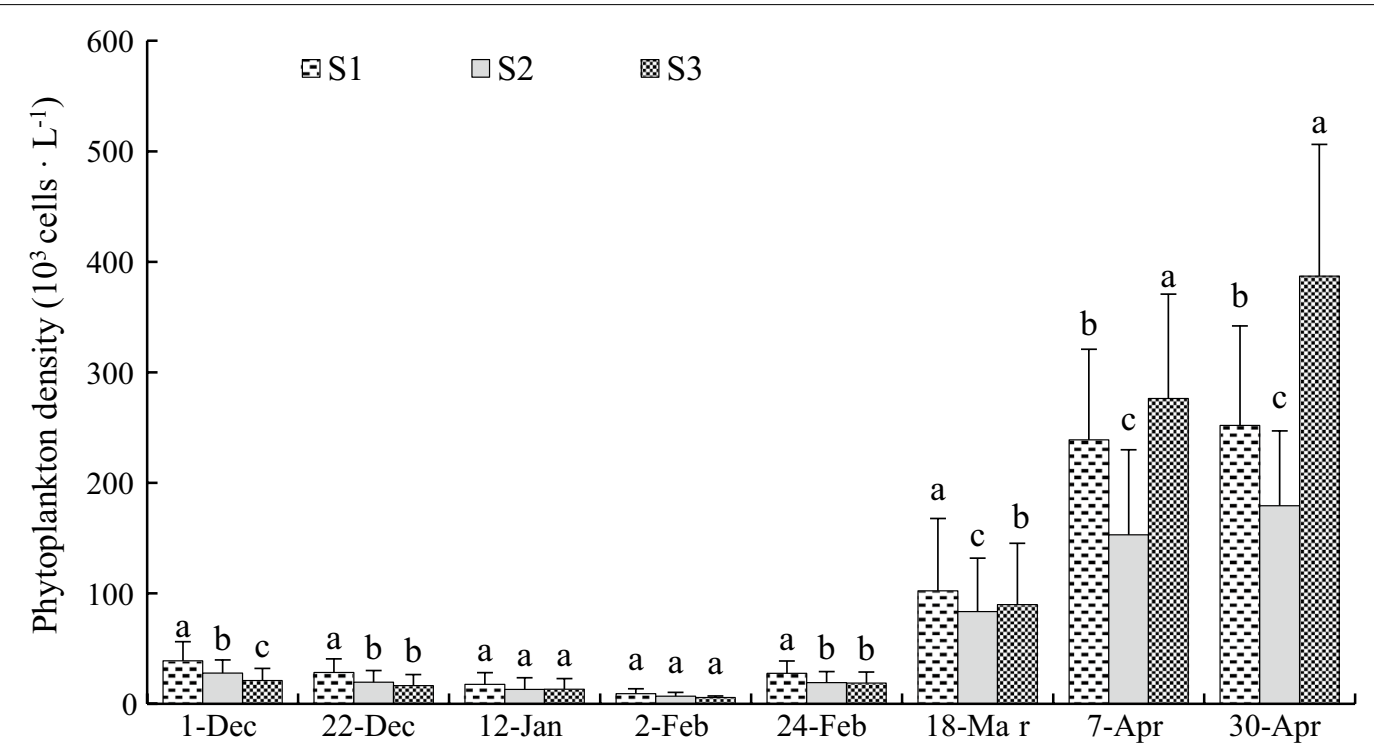

Fig. 9 Variation in phytoplankton density at sample stations. Different letters of the same sampling date indicate significant difference at 0.05

than that of other sample stations. The mean values of temperature in $\mathrm{S} 1, \mathrm{~S} 2$ and $\mathrm{S} 3$ was $10.5,8.8,8.1^{\circ} \mathrm{C}$, respectively, and this illustrates that the temperature elevation decreases as the distance from the outlet increases, which is in accordance with previous work Mei et al. [36].

Oysters are very sensitive to environmental change, and temperature variation greatly affects oyster growth. Researchers have shown that the growth of oyster shells is closely related to the source of food and the growth environment temperature; moreover, temperature elevation is beneficial to the growth of oyster shells in a suitable temperature range [37]. The present study showed that the $\mathrm{SH}$ of oysters cultured at $\mathrm{S} 1$ was greater than that of S3 from December 1, 2015 to March 18, 2016. We also found that the temperature at S1 was higher than at S3. The value of SL and SW showed a similar pattern at the same time points. These results indicate that the temperature elevation caused by thermal drainage promotes shell growth of oysters in low temperature season. The effect of thermal discharge is greater in winter than in 
summer [38,39], which means that the lower the natural seawater temperature, the greater the effect of thermal discharge on seawater temperature. Studies have shown that it is favorable for growing oysters when the temperature elevation is below $4{ }^{\circ} \mathrm{C}[40,41]$, and this may be the reason for the SH, SL and SW of oysters in sample S1 being greater than the other two sample stations before March 18, 2016.

The most important factor affecting reproduction is temperature [42, 43], and the gonadal development of marine bivalves have a close relationship with the fluctuation in the water temperature of their habitat [44]. The metabolism of bivalves is vigorous in the suitable temperature environment, and temperature elevation has positive effects on feeding, growth, gonadal development and reproduction [45]. The present study, however, leads to the opposite result. For instance, the S3 sample station, with the lowest temperature, had the highest GSI and MY during the trial. The GSI and MY of oysters at S1, with the highest temperature, was lower than that of S3. These results indicate that the temperature elevation caused by thermal discharge did not exert a positive effect on the gonadal and soft parts development of oysters, but conversely had an inhibitory effect. Especially after March 18, 2016, the GSI and MY showed significant increase at S3, however, the increment at S1 and S2 was not obvious. It has been shown that the effect of thermal discharge depends on ambient temperature regime [3]. Some marine animals may have already lived closer to the upper limit of lethal temperature and any further increased was more likely to affect them adversely, such as tropical region [46]. Researchers have showed that as soon as the lethal temperature is reached, the bivalves will die [2]. After March 18, 2016, temperature rise due to different seasons, the effect of thermal discharge was more obvious. Therefore, this may be the reason that GSI and MY at S1and S2 were lower than that of S3. We also found that the growth rate of GSI and MY at S3 was significantly higher than that at S2 and S1 (Fig. 10). This may result from that the temperature increment may not promote the growth of gonadal and soft parts of oysters due to the long-term influence of thermal discharge in high temperature season. However, the development of gonads depends not only on the water temperature but also on the accumulation of nutrients, and the accumulation of nutrients has a close relationship with bait quality and quantity. Therefore, the gonadal development of oysters is also influenced by the combination of bait, water environment and phytoplankton density $[47,48]$.

Temperature increment is easy to cause marine pollution, such as dissolved oxygen reduced [49], non-ionic ammonia increased [50], and even leads to the red tide [51, 52]. Oysters are filter feeders, and their gills are constantly exposed to the outside environment for filtration and respiration. The total ATPase activities in gill tissues will be reduced due to exposure of the polluted effluent over a long period of time $[19,53]$. This will reduce the filtration rate of the gills, while preventing the most direct energy conversion in the body [54]. Moreover, environmental pollution can reduce the growth rate of organisms, because the pressure of environmental pollution can lead to organisms use energy

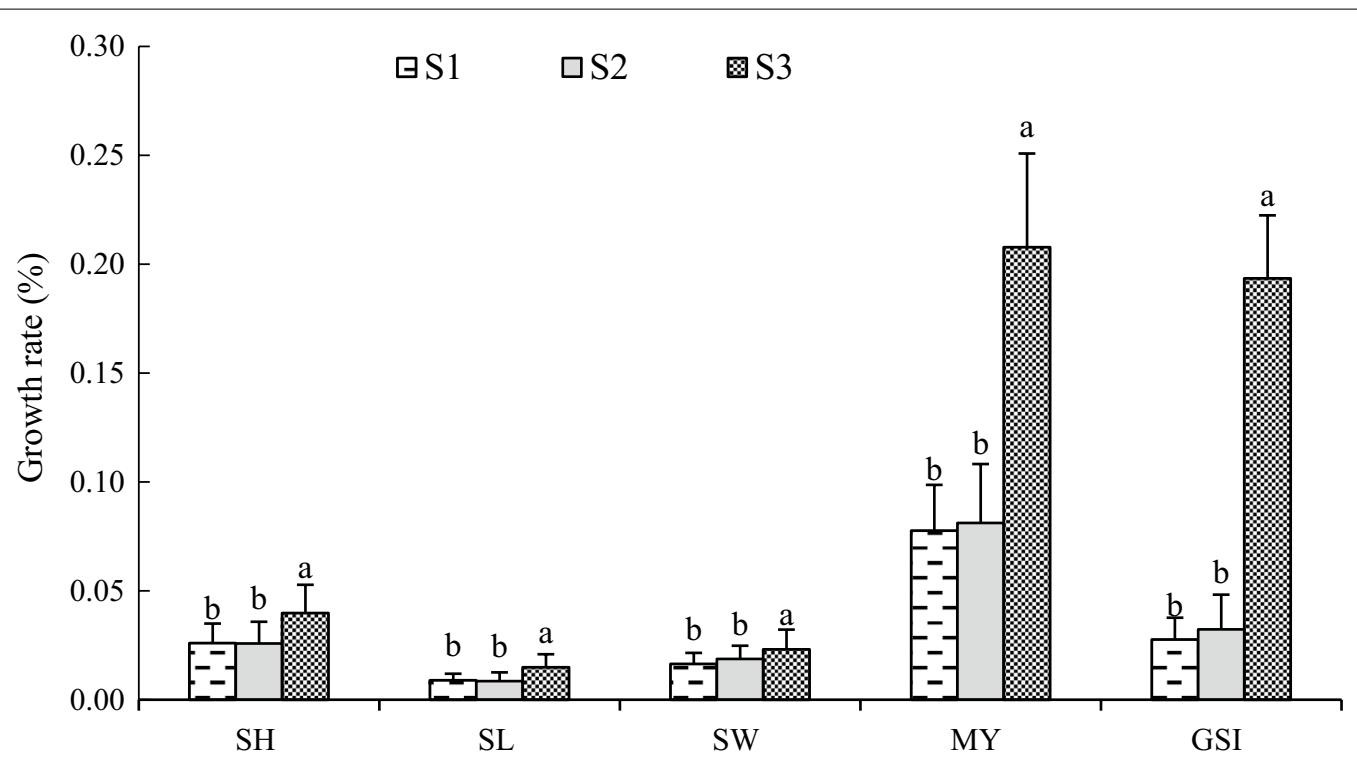

Fig. 10 The growth rate of oyster after March 18, 2016. Different letters of the same index indicate significant difference at 0.05 
to detoxify the body, which also depletes the energy reserves of the oyster $[55,56]$. It may also be the reason that the growth and development of GSI and MY are inhibited: on the one hand, it may be that temperature elevation has an inhibitory effect on the growth of the oyster, on the other hand, the change of other environmental factors that may be caused by thermal discharge affects the growth of oysters adversely.

Phytoplanktons are the base of aquatic food web and the most important source of food for bivalves. Temperature is a direct factor that affects the growth of phytoplankton [57], particularly in higher temperatures areas [58], and temperature elevation increases the abundance of temperature-tolerant taxa [59]. According to the study of Jiang et al. [60], the thermal discharge from Ninghai Power Plant increased the phytoplankton abundance in Xiangshan Bay. The present study was consistent with that conclusion, as the phytoplankton density at S1 was the highest from December 1, 2015 to March 18, 2016 (Fig. 9), and this trend seemed to be closely related to an increase in nutrients at S1 (Table 2). TP and TN are inorganic nutrients that can limit the phytoplankton production in tropical marine ecosystems [61]. The higher concentration of TP and TN may be increased the phytoplankton abundance. Therefore, the higher phytoplankton density may be the reason for the elevated growth of $\mathrm{SH}$, $\mathrm{SL}$ and SW at S1. Nevertheless, once the temperature of seawater rises beyond the optimum living temperature of aquatic organisms, it will adversely affect the survival, growth and reproduction of aquatic organisms [62]. This may explain why the phytoplankton density at S1 was lower than that of S3 after March 18, 2016. There was a significant growth of oyster shell at all sample stations after March 18, 2016, according to Moullac et al. [63], pearl oyster growth was correlated with Chl $a$ resources, which corresponded to food supply. In this study, the phytoplankton density rose sharply after February 24,2016 . Therefore, the increase of food and food categories maybe an important reason for the promotion of growth and development of oysters after March 18, 2016.

Table 2 Concentrations of total phosphorus (TP) and total nitrogen (TN) at sample stations

\begin{tabular}{lll}
\hline Sample stations & TP $(\mathbf{m g} / \mathbf{L})$ & TN $(\mathbf{m g} / \mathbf{L})$ \\
\hline S1 & $0.15 \pm 0.02^{\mathrm{a}}$ & $0.57 \pm 0.04^{\mathrm{a}}$ \\
S2 & $0.16 \pm 0.08^{\mathrm{a}}$ & $0.53 \pm 0.08^{\mathrm{a}}$ \\
S3 & $0.13 \pm 0.02^{\mathrm{b}}$ & $0.48 \pm 0.02^{\mathrm{b}}$ \\
\hline
\end{tabular}

Different letters of the same column indicate significant difference at 0.05

\section{Conclusion}

The present study delineated that thermal discharge from the nuclear power plant could affect the seawater temperature, nutrients, and phytoplankton density, especially the growth and development of the oysters. Temperature elevation caused by thermal discharge promotes the growth of oyster shells. Nevertheless, the growth of soft parts and gonad development are inhibited. The temperature increment may not promote the growth of gonadal and soft parts of oysters due to the long-term influence of thermal discharge. In consideration of the above muddling inferences, in order to optimize the development between mollusk culture and nuclear power, mollusk farming is not recommended near to nuclear power stations.

\section{Abbreviations}

TWNPP: Tianwan nuclear power plant; MY: meat yield; GSI: gonadosomatic index; SH: shell height; SL: shell length; SW: shell width; TN: total nitrogen; TP: total phosphorus.

\section{Authors' contributions}

ZGD conceived and designed the research. HXG, XYL and HLW partly performed the experiments and revised manuscript. CHW, ZH and YJW prepared and analyzed the data. YHC contributed to manuscript writing. JKL, GHF and $\mathrm{HC}$ partly provided experimental environment and editorial advice. All authors read and approved the final manuscript.

\section{Author details}

${ }^{1}$ Jiangsu Key Laboratory of Marine Bioresources and environment, Jiangsu Key Laboratory of Marine Biotechnology, Huaihai Institute of Technology, Lianyungang 222005, Jiangsu, China. ${ }^{2}$ Co-Innovation Center of Jiangsu Marine Bioindustry Technology, Lianyungang 222042, Jiangsu, China. ${ }^{3}$ Lianyungang City Marine and Fishery Development Promotion Center, Lianyungang 222000, Jiangsu, China. ${ }^{4}$ Lianyungang Muyang Aquaculture Co., Ltd., Lianyungang 222042, Jiangsu, China.

\section{Acknowledgements}

The authors would like to express our gratitude and appreciation to those who have spared their precious time to critically review this manuscript, and thanks to the PRS team for English proofreading, as well as undergraduates Chenhe Wang, Zhe Hu and Yangjian Wu in the Huaihai Institute of Technology for trial sample preparation.

\section{Competing interests}

The authors declare that they have no competing interests.

\section{Availability of data and materials}

The datasets analyzed during the current study are available from the corresponding author on reasonable request.

\section{Consent for publication}

Not applicable.

\section{Ethics approval and consent to participate}

All applicable institutional and/or national guidelines for the care and use of animals were followed.

\section{Funding}

This study was supported in part by Grants from the Jiangsu science and technology project (Nos. BN2015057 and BY2016056-07), the Project of Jiangsu Key Laboratory of Marine Biotechnology (No. 2014HS001), the Project of Lianyungang Science and Technology (No. CXY1511), China Agriculture Research System (CARS-49), the Priority Academic Program Development of Jiangsu 
Higher Education Institutions and Lianyungang Muyang Aquaculture Co., Ltd. commissioned research projects (technical services advisory of Integrated culture of large seaweed and oysters).

\section{Publisher's Note}

Springer Nature remains neutral with regard to jurisdictional claims in published maps and institutional affiliations.

Received: 22 December 2017 Accepted: 3 September 2018 Published online: 06 September 2018

\section{References}

1. Ren DX, Hu B. Global nuclear restart and china's road to big nuclear power producer and strong nuclear power producer. Sino-Global Energy. 2017;22(3):24-32.

2. Hussain KJ, Mohanty AK, Satpathy KK, Prasad MV. Abundance pattern of wedge clam Donax cuneatus (L.) in different spatial scale in the vicinity of a coastal nuclear power plant. Environ Monit Assess. 2010;163(1-4):185-94.

3. Barath-Kumar S, Mohanty AK, Satpathy KK, Das NPI. Impingement of marine organisms in a tropical atomic power plant cooling water system. Mar Pollut Bull Int J. 2017:124:555-62.

4. Liu YY, Chen XQ. Suggestion of the study on thermal impact of thermal discharge from NPPs. Radiat Prot Bull. 2011;31(6):20-3.

5. Hao RX, Liu F, Ren HQ, Chen SY. Study on a comprehensive evaluation method for the assessment of the operational efficiency of wastewater treatment plants. Stoch Environ Res Risk Assess. 2013;27(3):747-56.

6. Benedini M, Tsakiris $\mathrm{G}$. Water quality modelling for rivers and streams. Berlin: Springer; 2013

7. Karuppanapandian T, Karuppudurai T, Kumaraguru AK. A preliminary study on the environmental condition of the coral reef habitat. Int J Environ Sci Technol. 2007;4(3):371-8.

8. Apte SK. Impact assessment on the aquatic ecosystem in the vicinity of an operating nuclear power plant at the Kalpakkam Coastal Site. Proc Natl Assoc Sci India B. 2012;82(2):349-55.

9. Achary MS, Panigrahi S, Satpathy KK, Sahu G, Mohanty AK, Selvanayagam M, Panigrahy RC. Nutrient dynamics and seasonal variation of phytoplankton assemblages in the coastal waters of southwest Bay of Bengal. Environ Monit Assess. 2014;186(9):5681-95

10. Jiang ZB, Zeng JN, Chen QZ, Liao YB, Gao AG, Xu XQ, Shou L, Liu JJ, Huang $Y J$. Effect of heating rate on the upper incipient lethal temperature for copepods. J Trop Oceanogr. 2010;29(3):87-92.

11. Worthington TA, Shaw PJ, Daffern JR, Langford TEL. The effects of a thermal discharge on the macroinvertebrate community of a large British river: implications for climate change. Hydrobiologia. 2015;753(1):1-15.

12. Obrdlík P, Adámek Z, Zahrádka J. Mayfly fauna (Ephemeroptera) and the biology of the species Potamanthus /uteus (L.) in a warmed stretch of the Oslava River. Hydrobiologia. 1979;67(2):129-40.

13. Dallas HF, Ketley ZA. Upper thermal limits of aquatic macroinvertebrates: comparing critical thermal maxima with 96-LT 50 values. J Therm Biol. 2011;36(6):322-7.

14. Bobat A. Thermal pollution caused by hydropower plants. Energy systems and management. Berlin: Springer; 2015. p. 19-32.

15. Verlecar XN, Pereira N, Desai SR, Jena KB. Marine pollution detection through biomarkers in marine bivalves. Curr Sci. 2006;91(9):1153-7.

16. Shaw JP, Large AT, Donkin P, Evans SV, Staff FJ, Livingstone DR, Chipman JK, Peters LD. Seasonal variation in cytochrome P450 immunopositive protein levels, lipid peroxidation and genetic toxicity in digestive gland of the mussel Mytilus edulis. Aquat Toxicol. 2004;67(4):325-36.

17. Ricciardi F, Binelli A, Provini A. Use of two biomarkers (CYP450 and acetylcholinesterase) in zebra mussel for the biomonitoring of Lake Maggiore (northern Italy). Ecotoxicol Environ Saf. 2006;63(3):406-12.

18. Amoozadeh E, Malek M, Rashidinejad R, Nabavi S, Karbassi M, Ghayoumi R, Ghorbanzadeh-Zafarani G, Salehi H, Sures B. Marine organisms as heavy metal bioindicators in the Persian Gulf and the Gulf of Oman. Environ Sci Pollut Res. 2014;21(3):2386-95.
19. Domingos FXV, Azevedo M, Silva MD, Randi MA, Freire CA, Silva de Assis HC, Oliveira Ribeiro CA. Multibiomarker assessment of three Brazilian estuaries using oysters as bioindicators. Environ Res. 2007;105(3):350-63.

20. Bigas M, Durfort M, Poquet M. Cytological response of hemocytes in the European flat oyster, Ostrea edulis, experimentally exposed to mercury. Biometals. 2006;19(6):659-73.

21. Bernal-Hernández YY, Medina-Díaz IM, Robledo-Marenco ML, VelázquezFernández JB, Girón-Pérez MI. Acetylcholinesterase and metallothionein in oysters (Crassostrea corteziensis) from a subtropical Mexican Pacific estuary. Ecotoxicology. 2010;19(4):819-25.

22. Sarma K, Anand KA, Krishnan P, George G, Prabakaran K, Roy SD, Srivastava RC. Impact of coastal pollution on biological, biochemical and nutritional status of edible oyster in Phoenix Bay Jetty and North Wandoor of Andaman. Indian J Anim Sci. 2013;83(3):321-5.

23. Fishery Bureau of China. China fisheries statistics yearbook. Beijing: China Agriculture Press; 2016. p. 29.

24. Wu JX, Yan BL, Feng JH, Li Y, Xu JT, Li SH, Shen X. Zooplankton ecology near the Tianwan Nuclear Power Station. Acta Ecol Sin/Shengtai Xuebao. 2011;31(22):6902-11.

25. Cheng JP, Yan LM, Li FC. CFD simulation of a four-loop PWR at asymmetric operation conditions. Nucl Eng Des. 2016;300:591-600.

26. Ji ZZ, Yang Y, Zhang LB, Wu SY. Issues considered in general layout of water intake structure for Tianwan nuclear power station. China Harb Eng. 2005;2:17-20.

27. Kennedy VS, Newell RIE, Eble AF. The Eastern oyster: Crassostrea virginica. College Park: Maryland Sea Grant College, University of Maryland, 1996. p. $1-734$.

28. Harding JM, Mann R. Age and growth of wild Suminoe (Crassostrea ariakensis, Fugita 1913) and Pacific oyster (C. gigas, Thunberg 1793) from Laizhou Bay, China. J Shellfish Res. 2006;25(1):73-82.

29. Zhong XX, Li, Kong LF, Yu H, Guo X. Quantitative trait locus analysis of meat yield and shell shape traits in the Pacific oyster, Crassostrea gigas. J Fish Sci China. 2015;22(3):574-9.

30. Kraffe E, Tremblay R, Belvin S, Lecoz JR, Marty Y, Guderley H. Effect of reproduction on escape responses, metabolic rates and muscle mitochondrial properties in the scallop Placopecten magellanicus. Mar Biol. 2008;156(1):25-38.

31. Wan Y, Yang H, Liu JT, Ma RM, Cheng XS, Wang C, Ge XJ, Zhu XY. Changes of net-collected phytoplankton community in sea area adjacent to Tianwan Nuclear Power Plant of Lianyungang. Acta Agric Univ Jiangxi. 2014;26(5):104-9.

32. Fritsch FE. The structure and reproduction of the algae. London: The syndics of Cambridge University Press; 1975.

33. Cao X, Song C, Li Q, Zhou Y. Dredging effects on P status and phytoplankton density and composition during winter and spring in Lake Taihu, China [M]//Eutrophication of shallow lakes with special reference to Lake Taihu, China. Netherlands: Springer; 2007.

34. Li M, Cai ZP. Effects of nuclear power plants on ocean-environment and organisms: a review. Mar Sci. 2001;25(9):32-5.

35. Riera R, Núñez J, Martín D. Effects of thermal pollution on the softbottoms surrounding a power station in the Canary Islands (NE Atlantic ocean). Oceanology. 2011;51(6):1040-6.

36. Mei LY, Cai XB, Lai MD, Zhou XZ, Zhuang YX. Retrospective evaluation research of marine ecological effects of warm water drainage from Mawan power Plant in Shenzhen. Environ Eng. 2012;30:349-51.

37. Elfwing T, Blidberg E, Sison M, Tedengren M. A comparison between sites of growth, physiological performance and stress responses in transplanted Tridacna gigas. Aquaculture. 2003;219(1-4):815-28.

38. Zhang HR, Zhao Y, Yang H, Chen BR, Ding J, Dai ZX, Du PJ. Study on the temperature rise characteristics and influence effects of thermal discharge from coastal power plant in Xiangshan Bay. J Shanghai Ocean Univ. 2013;22(2):274-81.

39. Jia HL, Xie J, Zhang J, Zhang SL, Liu LF, Gu W. Distribution of warm discharge water and cooling effect of drainage engineering at the Zhuhai Power Station. Coast Eng. 2014;33(3):1-9.

40. Wu J, Hang SF, Yang ZS. Effects of thermal discharge on aquatic ecosystems and the mitigation countermeasures. Environ Sci Technol. 2006;29(s1):127-9.

41. Chen CW, Weintraub LHZ, Herr J, Goldstein RA. Impacts of a thermal power plant on the phosphorus TMDL of a reservoir. Environ Sci Policy. 2000:2000(3):217-23. 
42. Lan ZG, Li XZ, Xiao G, Liu C. Potential impacts of thermal discharge on marine environment from offshore floating nuclear power plant. Mar Sci. 2016;40(6):84-8.

43. Li XY, Li B, Sun XL. Effects of a coastal power plant thermal discharge on phytoplankton community structure in Zhanjiang Bay, China. Mar Pollut Bull. 2014;81(1):210-7.

44. Cao Y, Chen AH, Yao GX, Zhang Y, Wu YP, Wang C, Cai YX, Zhang ZW. The distribution and reproduction regularity of the oysters in the Xiaomiaohong oyster reef. J Aquac. 2015:36(4):29-33.

45. Wang RC, Wang ZP. Science of marine shellfish culture. Qingdao: Ocean University of China Press; 2008. p. 9.

46. Saravanane N, Satpathy KK, Nair KVK, Durairaj G. Preliminary observations on the recovery of tropical phytoplankton after entrainment. Ther Biol Int J. 1998;23(2):91-7.

47. Cross ME. O'Riordan RM, Culloty SC. The reproductive biology of the exploited razor clam, Ensis siliqua, in the Irish Sea. Fish Res. 2014;150(150):11-7

48. Liu WG, Li Q, Gao F, Kong LF. Effect of starvation on biochemical composition and gametogenesis in the Pacific oyster Crassostrea gigas. Fish Sci. 2010:76(5):737-45.

49. Mayhew DA, Jensen LD, Hanson DF, Muessig PH. A comparative review of entrainment survival studies at power plants in estuarine environments. Environ Sci Policy. 2000;3(3):295-301.

50. Ficke AD, Myrick CA, Hansen L. Potential impacts of global climate change on freshwater fisheries. Rev Fish Biol Fish. 2007;17(4):581-613.

51. Gao L, Zhou J, Yang H, Chen J. Phosphorus fractions in sediment profiles and their potential contributions to eutrophication in Dianchi Lake. Environ Geol. 2006;49(5):792.

52. Huang $X C$, Chen $X C$, Peng $X$, Zhang $R$, Qing $X Y$, Tang J. The research progress of the impact of thermal discharge from coastal power plants on marine environment. Mar Environ Sci. 2014;33(6):972-6.

53. Parvez S, Sayeed I, Raisuddin S. Decreased gill ATPase activities in the freshwater fish Channa punctata (Bloch) exposed to a diluted paper mill effluent. Ecotoxicol Environ Saf. 2006;65(1):62-6.
54. Seetharaman P, Sarma K, George G, Krishnan P, Roy SD, Sankaret K. Impact of coastal pollution on microbial and mineral profile of edible oyster (Crassostrea rivularis) in the coastal waters of Andaman. Bull Environ Contam Toxicol. 2015;95(5):1-7.

55. Lucas A, Beninger PG. The use of physiological condition indices in marine bivalve aquaculture. Aquaculture. 1985;44(3):187-200.

56. Nicholson S, Lam PK. Pollution monitoring in Southeast Asia using biomarkers in the mytilid mussel Perna viridis (Mytilidae: Bivalvia). Environ Int. 2005:31(1):121-32.

57. Liu HX, Li KZ, Huang HH, Song XY, Yin JQ, Huang LM. Seasonal community structure of mesozooplankton in the Daya Bay, South China Sea. J Ocean Univ China. 2013;12(3):452-8.

58. Smita-Achary M, Sahu G, Mohanty AK, Samatara MK, Panigraghy S, Selvanayam M, Satpathy KK, Prasad MVR, Panigraghy RC. Phytoplankton abundance and diversity in the coastal waters of Kalpakkam, east coast of India in relation to the environmental variables. Biol Int J. 2010;2:553-68.

59. Wang ZH, Qi YZ, Chen JF, Xu N, Yang YF. Phytoplankton abundance, community structure and nutrients in cultural areas of Daya Bay, South China Sea. J Mar Syst. 2006;62(1-2):85-94.

60. Jing ZB, Zhu XY, Gao Y, Chen QZ, Zeng JN, Zhu GH. Spatio-temporal distribution of net-collected phytoplankton community and its response to marine exploitation in Xiangshan Bay. Chin J Oceanol Limnol. 2013;31(4):762-73 (English).

61. Mohanty AK, Sahu G, Bramha SN, Samantara MK, Satpathy KK. Assessment of temporal variation in coastal water characteristics through multivariate statistics-a case study at southwestern Bay of Bengal, India. Mar Sci J Ind. 2014:43(9):1718-31.

62. He YY. A pondering over research on environment thermal impact of cooling water discharged from groups of power plants. Adv Sci Technol Water Resour. 2008;28:27-9.

63. Moullac GL, Tiapari J, Teissier H, Martinez E, Cochard JC. Growth and gonad development of the tropical black-lip pearl oyster, Pinctada margaritifera (L.), in the Gambier archipelago (French Polynesia). Aquac Int. 2012;20(2):305-15.
Ready to submit your research? Choose BMC and benefit from:

- fast, convenient online submission

- thorough peer review by experienced researchers in your field

- rapid publication on acceptance

- support for research data, including large and complex data types

- gold Open Access which fosters wider collaboration and increased citations

- maximum visibility for your research: over $100 \mathrm{M}$ website views per year

At $\mathrm{BMC}$, research is always in progress.

Learn more biomedcentral.com/submissions 